\title{
IMPACT OF TRAINING AND COMPENSATION PRACTICES ON PERFORMANCE OF SMALL AND MEDIUM SIZED MANUFACTURING ENTERPRISES
}

\author{
DR. RAVI K S, DR. KHALID IMRAN, DR. G V NAVEEN PRAKASH \& NAVEEN A
}

Department of Mechanical Engineering, Vidyavardhaka College of Engineering, Mysuru, Karnataka, India

\begin{abstract}
Organizations cannot get candidates who exactly match with the job and the organizational requirements. Hence training is important to develop the skills of employees and make him suitable for the job. Every organization small or large, old or newly started should provide training to all employees irrespective of their qualification, skill, appropriateness for the job etc. Compensation is one of the extrinsic practices of human resource function in an organization. Basic salary is included under direct compensation, while benefits are included under indirect compensation and may consist of health insurance, the employers' contribution to retirement, pay for illness. The questionnaire was developed and measured by using a five point Likert scales ranging from strongly disagree to strongly agree. ANOVA and Chi-square test was used to examine the impact of formal and informal adoption of training and compensation practices on organizational performance. The results revealed that there is an association between those organizations who adopt formal or informal training and compensation practices with financial performance of small and medium sized enterprises. Also the results shows that there is a significant difference in the mean agreeability scores on financial performance of SMEs and the mean agreeability scores are high among the enterprises that adopt formal training and compensation practices.

KEYWORDS: Training, Compensation, Financial Performance, Small and Medium Sized Enterprises
\end{abstract}

Received: Jun 06, 2020; Accepted: Jun 26, 2020; Published: Aug 06, 2020; Paper Id.: IJMPERDJUN2020661

\section{INTRODUCTION}

Every organization requires trained and experienced personnel to perform the activities in the industry. Training shapes the employees' knowledge, skills, behaviour, aptitude and attitude towards the requirement of the job and the organization. Employee training is a specialized function and is one of the primary operative functions for human resource management. After an employee is selected, placed and introduced, he or she must be provided with training facilities. Training helps to enhance the knowledge and ability of an employee for accomplishment of a particular work. Training is the most important technique of human resource development. Organizations cannot get candidates who exactly match with the job and the organizational requirements. Hence training is important to develop the employee and make him suitable to the job.

Training is a short-term educational process and employs a methodical and structured procedure by which employees' gain technical knowledge and skill for a specific purpose. Thus, training bridges the gap between job requirement and employees current knowledge.

Compensation management is one of the important factors in human resource management. So an effective compensation system is more significant as several problems relating to personnel centre around compensation. Many employees, absent themselves from work often because they feel they are not paid enough. They look for new and better prospects. Hence an attractive compensation policy has to be followed by the organizations [1]. 
Compensation may be defined as money received for the performance of work and many kinds of benefits and services that organizations provide to their employees. Basic salary is included under direct compensation, while benefits are included under indirect compensation and may consist of health insurance, the employers' contribution to retirement, pay for illness etc.

The soundness of compensation depends upon the extent of wage or salary paid to an employee for a fair days work. It is significant to most of the employees as it constitutes a major share of their income. Salary is one of the important motivational factors in our society. Salary provides a means of satisfying the physical needs and determines the social status. Hence formulation of sound compensation policy to attract and retain right personnel in right position is the main responsibility of any organization. Compensation influences the survival and growth of an organization to the greatest extent [2].

\section{LITERATURE REVIEW}

John [3] carried-out a study on training and compensation and manufacturing performance, and flexible production systems of auto industry in United States. He highlights that extensive training and good compensation will enhance the performance of the production plants.

A study conducted at large and small Canadian manufacturing firms by Damodhar and Satish [4] found that, in order to retain their employees, small firms have to develop suitable compensation policies. They found that Small firms have to train the employees who lack required skills.

Malcolm et al. [5] studied the impact of training and reward practices on business performance in United Kingdom manufacturing firms. Performance measures considered are worker productivity and profits. Their study revealed that training practices and reward systems influence organization's performance. According to them more satisfied workers contribute significantly towards productivity and profitability.

A study conducted by Vijaya [6] on small and medium sized enterprises (SMEs) in Atlanta, reveals that training practices can vary with the size of the company and can be quite different between large and small businesses and the success of small businesses can depend heavily upon its training practices. Further, on-the-job or off-the-job training is prevalent as expected by employees. Also it was highlighted that fringe benefits are considered as an important element in attracting prospective employees. Incentives such as bonuses, profit sharing or stock options are provided in most small and medium size companies.

Chandler et al. [7] found that providing group based incentive system helps in lower employee turnover and enhanced performance of organization. And also they are of the opinion that, by investing in employee training helps in lower employee turnover and enhanced performance of organization.

Renee and John [8] carried out a study at Northern Ireland. They explored that performance related pay packages are common in non-family firms. Also they found that family businesses use reward systems for manual workers than nonfamily businesses. They highlighted that family businesses have less percentage of HRM department than non-family businesses. Training is a challenging task for family and non-family businesses. Family businesses spend less on training of employees. 
Robert [9] examined training, compensation and benefit packages in small manufacturing companies of Southeastern USA. In order to retain best employees competitive compensation packages are important for companies. They identified that organizations success also depends on sharing profits with them. According to him recognizing and honouring the employees leads to organization success. He found that training helps to increase the company profits. He also found that by adopting training practices small businesses can witness low employee turn-over

Catherine et al. [10] carried-out a study at European SMEs. According to them training activities are common in all firms; however the quantum of training provided is not adequate. Their findings suggest that some firms use incentive schemes but have faced some problems in the use of such schemes

Jan et al. [11] explored training and compensation practices in Dutch SMEs. They highlighted that firm size has influence on formalization of training practices. The formal training practices improve employee competence and commitment. Further, firm size is positively related with the probability that human resource department is present and in turn encourages the formality of training policies and practices. The formal compensation practices improve employee competence and commitment.

A study carried-out by Claire [12] at New Zealand SMEs reveals that the performance and economic growth can be expected by employing pay for performance scheme. Also his research explores that in small firms training is informal and performance of small firms is less compared to large firms. Further the study highlights that the performance and economic growth can be expected by employing good training practices.

Jyothi [13], in her article found that most of the small firm's do not spend on training and development in India. Further research reveals that performance of employees is not linked with rewards.

A study conducted by Kuldeep [14] at Indian SMEs. Eighty two industries were considered in his study. He found that there is a significant relationship between the training and organizational and market performance of the firms. Also he found that there is a significant relationship between compensation and perceived organizational and market performance of the firms

\section{METHODOLOGY}

The objective of the research was to find the significance and association of formal or informal adoption of training and compensation practices with financial performance of selected SMEs using One-Way ANOVA and Chi-Square test.

The study is confined to mechanical manufacturing sectors in Mysore and Bangalore regions of Karnataka, India. Karnataka is recognized as one of the major industrial hub with more number of diversified industries. Study draws its finding based on responses of owners/managers of SMEs which will give the insight into training and compensation practices and SMEs performance

As per many researchers and academicians, human resource management (HRM) is related to large organizations and recognize the management of human resources as a critical factor in their success or failure[15] [16]. Does this equally apply to small and medium enterprises? [17] [18].

Descriptions of formal and informal adoption of training and compensation practices in SMEs are shown below:

- Formal adoption of training practices: SMEs have a program and budget for employee training [19]. 
- Formal adoption of compensation practices: SMEs have a proper procedure for compensation and rewards. All the formal procedures in terms of qualification, grade, experience of the candidates and other such criteria are considered.

- Informal adoption of training practices: Training is mostly individual's responsibility. Budget for training is very small or non-existent in SMEs [19].

- Informal adoption of Compensation practices: No written criteria or rule. Based on the demand and supply depending upon the requirement and the market trend and each individual is either compensated or rewarded on a case-by-case basis.

\section{Research Hypothesis}

The following null hypothesis and alternate hypothesis are formulated and tested.

\section{1) Null Hypothesis}

- There is no significant association between those organizations who adopt formal training practices and those organizations who do not adopt formal training practices and their financial performance.

- There is no significant association between those organizations who adopt formal compensation practices and those organizations who do not adopt formal compensation practices and their financial performance.

\section{2) Alternate Hypothesis}

- There is a significant association between training practices and financial performance of SMEs.

- There is a significant association between compensation practices and financial performance of SMEs.

\section{Research Instrument}

The questionnaire covers questions on training practices, compensation practices and organizational performance in terms of financial measures. All the questions framed were closed ended type with a five point Likert scales ranging from strongly disagree to strongly agree.

\section{Results and Discussions}

a) The analysis of variance has been carried out based on formal or informal adoption of training and compensation practices by the SMEs and the mean agreeability scores of the respondents representing various SMEs on the financial of the organization. Table 1 and Table 2 shows overall mean agreeability scores on financial performance among the respondents representing the enterprises that adopt or do not adopt any formal training and compensation practices. 
Table 1: ANOVA - Training Practices and Financial Performance of SMEs

\begin{tabular}{|c|c|c|c|c|c|c|}
\hline \multirow{3}{*}{ Training Practices } & \multirow{2}{*}{\multicolumn{2}{|c|}{ Respondents }} & \multicolumn{4}{|c|}{ Financial Performance of SMEs } \\
\hline & & & \multirow{2}{*}{ Mean } & \multicolumn{2}{|c|}{ Range } & \multirow{2}{*}{ S.D. } \\
\hline & $\mathbf{N}$ & $\%$ & & Min. & Max. & \\
\hline Formal Adoption & 76 & 19.8 & 4.68 & 3 & 5 & 0.594 \\
\hline Informal Adoption & 308 & 80.2 & 3.06 & 1 & 5 & 1.493 \\
\hline \multirow[t]{2}{*}{ Total } & 384 & 100 & 3.38 & 1 & 5 & 1.509 \\
\hline & \multicolumn{5}{|c|}{ F val.(df: 1,382$)=86.975^{*}$} & \\
\hline
\end{tabular}

Table 1 shows the results of ANOVA for the dimension training practices with respect to financial performance of SMEs. It is seen that $80.20 \%$ of the SMEs are not adopting formal training practices, whereas only $19.80 \%$ of the SMEs adopt formal training practices. The analysis of variance shows that there is a significant difference in the mean scores among the respondents on financial performance of SMEs. The mean score is 4.68 for formal adoption of training practices and is higher than the mean score of 3.06 for informal adoption of training practices.

A mean value of 4.68 reveals that, the respondents are highly satisfied with the financial performance of SMEs when formal training practices are adopted. Also a mean value of 3.06 indicates that the respondents are not satisfied with the financial performance when informal training practices are adopted by SMEs.

Table 2: ANOVA - Compensation Practices and Financial Performance of SMEs

\begin{tabular}{|c|c|c|c|c|c|c|}
\hline \multirow{3}{*}{ Compensation Practices } & \multirow{2}{*}{\multicolumn{2}{|c|}{ Respondents }} & \multicolumn{4}{|c|}{ Financial Performance of SMEs } \\
\hline & & & \multirow{2}{*}{ Mean } & \multicolumn{2}{|c|}{ Range } & \multirow{2}{*}{ S.D. } \\
\hline & $\mathbf{N}$ & $\%$ & & Min. & Max. & \\
\hline Formal Adoption & 72 & 18.75 & 4.61 & 1 & 5 & 0.797 \\
\hline Informal Adoption & 312 & 81.25 & 3.09 & 1 & 5 & 1.492 \\
\hline \multirow[t]{2}{*}{ Total } & 384 & 100 & 3.38 & 1 & 5 & 1.509 \\
\hline & \multicolumn{5}{|c|}{ F val. $(\mathrm{df}: 1,382)=69.846^{*}$} & \\
\hline
\end{tabular}

Source: Primary Data

*Significant at $5 \%$

Table 2 reveals that $81.25 \%$ of the SMEs are not adopting formal compensation practices, whereas only $18.75 \%$ of the SMEs adopt formal compensation practices. The analysis of variance shows that there is a significant difference in the mean scores among the respondents on financial performance of SMEs. The mean score is 4.61 for formal adoption of compensation practices and is higher than the mean score of 3.09 for informal adoption of compensation practices.

A Mean value of 4.61 indicates that the respondents are highly satisfied with the financial performance when formal compensation practices are adopted by SMEs. Also a mean value of 3.09 indicates that the respondents are not satisfied with the financial performance when informal compensation practices are adopted by SMEs.

b) Chi-square test was conducted to check the association of training and compensation practices with financial performance of the manufacturing SMEs in Mysore and Bangalore region of Karnataka, India. Table 3 and Table 4 shows the results. 
Table 3: Association between Training Practices and Financial Performance of SMEs

\begin{tabular}{|c|c|c|c|c|c|c|}
\hline \multirow[b]{2}{*}{ Training Practices } & \multicolumn{5}{|c|}{ Financial Performance of SMEs } & \multirow[b]{2}{*}{ Total } \\
\hline & $\begin{array}{l}\text { Strongly } \\
\text { Disagree }\end{array}$ & Disagree & $\begin{array}{l}\text { Neither } \\
\text { Agree nor } \\
\text { Disagree }\end{array}$ & Agree & $\begin{array}{c}\text { Strongly } \\
\text { Agree }\end{array}$ & \\
\hline Formal Adoption & $\begin{array}{c}0 \\
(8.3) \\
\end{array}$ & $\begin{array}{c}0 \\
(21.8) \\
\end{array}$ & $\begin{array}{c}5 \\
(9.5) \\
\end{array}$ & $\begin{array}{c}14 \\
(5.7) \\
\end{array}$ & $\begin{array}{c}57 \\
(30.7) \\
\end{array}$ & 76 \\
\hline Informal Adoption & $\begin{array}{c}42 \\
(33.7)\end{array}$ & $\begin{array}{c}110 \\
(88.2)\end{array}$ & $\begin{array}{c}43 \\
(38.5)\end{array}$ & $\begin{array}{c}15 \\
(23.3)\end{array}$ & $\begin{array}{c}98 \\
(124.3) \\
\end{array}$ & 308 \\
\hline Total & 42 & 110 & 48 & 29 & 155 & 384 \\
\hline
\end{tabular}

Source: Primary Data *Significant at $5 \%$

With respect to table 3 the results are presented as follows:

The expected frequencies are given in the parenthesis the table 3.
Chi-Square Value: 83.146*
D.F: 4
$\mathrm{p}=0.002$

As the $\chi^{2}$ value is statistically significant, the null hypothesis which states that "there is no significant association between training practices and financial performance of SMEs is rejected". Alternate hypothesis is accepted. This reveals there is a significant association between training practices and their financial performance.

Also as the observed frequencies (i.e. agree and strongly agree frequencies) are higher than the expected frequencies among SMEs that have adopted formal training practices, it is inferred that formal adoption of training practices have significant impact on the financial performance of SMEs than the other group.

Table 4: Association between Compensation practices and Financial Performance of SMEs

\begin{tabular}{|c|c|c|c|c|c|c|}
\hline \multirow[b]{2}{*}{$\begin{array}{l}\text { Compensation } \\
\text { Practices }\end{array}$} & \multicolumn{5}{|c|}{ Financial Performance of SMEs } & \multirow[b]{2}{*}{ Total } \\
\hline & $\begin{array}{l}\text { Strongly } \\
\text { Disagree }\end{array}$ & Disagree & $\begin{array}{l}\text { Neither } \\
\text { Agree nor } \\
\text { Disagree }\end{array}$ & Agree & Strongly Agree & \\
\hline Formal Adoption & $\begin{array}{c}1 \\
(7.9) \\
\end{array}$ & $\begin{array}{c}1 \\
(20.6) \\
\end{array}$ & $\begin{array}{c}5 \\
(9.0) \\
\end{array}$ & $\begin{array}{c}11 \\
(5.4) \\
\end{array}$ & $\begin{array}{c}54 \\
(29.1) \\
\end{array}$ & 72 \\
\hline Informal Adoption & $\begin{array}{c}41 \\
(34.1)\end{array}$ & $\begin{array}{c}109 \\
(89.4)\end{array}$ & $\begin{array}{c}43 \\
(39.0)\end{array}$ & $\begin{array}{c}18 \\
(23.6)\end{array}$ & $\begin{array}{c}101 \\
(125.9)\end{array}$ & 312 \\
\hline Total & 42 & 110 & 48 & 29 & 155 & 384 \\
\hline
\end{tabular}

Source: Primary Data *Significant at $5 \%$

With respect to table 4 the results are interpreted as follows:

The expected frequencies are given in the parenthesis of the table 4.

Chi-Square Value: $65.897 * \quad$ D.F: $4 \quad p=0.001$

As the $\chi^{2}$ value is statistically significant, the null hypothesis which states that "there is no significant association between compensation practices and financial performance of SMEs is rejected". Alternate hypothesis is accepted. Hence it reveals that there is a significant association between compensation practices and their financial performance.

Also as the observed frequencies (i.e. agree and strongly agree frequencies) are higher than the expected frequencies among SMEs that have adopted formal compensation practices, it is inferred that formal adoption of compensation practices significantly influence the financial performance of SMEs than the other group. 


\section{CONCLUSIONS}

The analysis of variance shows that there is significant difference in the mean agreeability scores on financial performance of SMEs and the mean agreeability scores are high among the enterprises that adopt formal training and compensation practices. Also it is concluded that training and compensation practices are significant with respect to financial performance of SMEs. However formal adoption of training and compensation practices increases the financial performance of SMEs. The Chi-square test reveals that there is an association between those organizations who adopt formal training and compensation practices and their financial performances. Nevertheless the SMEs which have adopted formal training and compensation practices have exhibited better financial performance than those SMEs which have adopted informal training and compensation practices.

\section{REFERENCES}

1. K Aswathappa, Human Resource Management, text and cases, 6th edition, Tata McGraw Hill Education private limited, New Delhi 2010.

2. P. Subba Rao, Essentials of Human resource management and industrial relations, Himalaya publishing house, second revised edition, Mumbai 2005.

3. Ramakrishnan, V., S. Nallusamy, and M. Rajaram Narayanan. "Study on lean tools implementation in various Indian small and medium scale manufacturing industries." International Journal of Mechanical and Production Engineering Research and Development, 8 (1), 969976 (2018).

4. John Paul Macduffie (1995), "Human resource and manufacturing performance, organization logic and flexible production systems in the auto industry”, Industrial \& labour relations Review, Vol. 48, No.2, pp. 197-221.

5. Damodhar. Y. Golhar and Satish P. Deshpande (1997), "HRM practices in large and small Canadian manufacturing firms", Journal of small business Management, Vol. 35, No.3, pp. 30-38.

6. Malcolm G. Patterson, Michael A West, Rebecca Lawthom, Stephen Nickell (1998), "Impact of People Management Practices on Business Performance”, Institute of Personnel and Development, IPD House, Camp Road, London, ISBN: 085292725.

7. Shrimali, Arvind Kumar, and Vimlesh Kumar Soni."A review on issues of lean manufacturing implementation by small and medium enterprises." International Journal of Mechanical and Production Engineering Research and Development (IJMPERD) 7.3 (2017): 283-300.

8. Vijaya S. Perumalla (2000), "Profiles and HRM Practices of Small and Medium-scale Businesses in Atlanta”, School of Public Policy Georgia Institute of Technology, Atlanta, Georgia, Retrieved on January 2010.

9. Chandler, Gaylen N., McEvoy, Glenn M. (2000), "Human Resource Management, TQM, and Firm Performance in Small and Medium-Size Enterprises", Academic Journal Article, Entrepreneurship: Theory and Practice, Vol. 25, No. 1, pp. 43-57.

10. Renee S Reid, John S Adams (2001), "Human resource management - a survey of practices within family and non-family firms", Journal of European Industrial Training, Vol.5, No. 6/7, ABI/INFORM Research, pp. 310-320.

11. Meeradevi, M., Nancy Das, and P. Maria Doss. "Performance of ICT on Small and Medium Enterprises in Cuddalore District. "International Journal of Business Management \& Research (IJBMR) 10. 1, Feb 2020, 53-58

12. Robert W. Rowden (2002), "High performance and human resource characteristics of successful small manufacturing and processing companies”, Leadership and Organization Development Journal, Vol.23, No.1/2, pp. 79-83. 
13. Catherine Cassell, Sara Nadin, Melanie Gray, Chris Clegg (2002), "Exploring human resource management practices in small and medium sized enterprises", Personal Review, Vol.31, No. 5/6, pp. 671-692.

14. Jan de Kok, Roy Thurik, Lorraine Uhlaner (2006), "Professional HRM Practices in Family Owned-Managed Enterprises", Journal of Small Business Management, Vol. 44, No. 3, pp. 441-460.

15. Claire Massey (2004), “Employee practices in New Zealand SMEs: Employee Relations”, Vol.26, No.1/2, pp. 94-105.

16. Jyothi P. (2004), "Practices of HR Functions in a Small Scale Organisation”, SEDME, Vol.31, No.4, pp.19-26.

17. Kuldeep Singh (2004), "Impact of HR practices on perceived firm performance in India", Asia Pacific Journal of Human Resources, Vol. 42, No. 3, pp. 301-317.

18. Chitte, Pritish, et al. "Design and Fabrication of Automated Pneumatic Shearing Machine to Cut Aluminium Sheet"." International Journal of Mechanical and Production Engineering Research and Development, p-ISSN (2018): 22496890 (2018).

19. Mark A. Huselid (1995), "The impact of human resource Management practices on turnover, productivity and corporate financial performance", Academy of management journal, Vol. 38, No. 3, pp. 635-872.

20. Mathew Ray Allen (2006), "Strategic Human Resource Management and Firm Performance: What Can We Learn from Small Businesses", A Dissertation Presented to the Faculty of the Graduate School of Cornell University, New York.

21. Debi S. Saini, Pawan S. Budhwar (2008), "Managing the human resource in Indian SMEs: The role of indigenous realities", Journal of World Business, Vol.43, pp. 417-434.

22. Jeffrey S. Hornsby, Donald F. Kuratko, (1990), "Human Resource Management As Small Businesses Grow”, American Journal of Business, Vol. 5, Issue 1, pp. $31-38$.

23. Thang V. Nguyen, Scott E. Bryant (2004), “A Study of the Formality of Human Resource Management Practices in Small and Medium-Size Enterprises in Vietnam”, International Small Business SAGE Publications (London, Thousand Oaks and New Delhi) [DOI: 10.1177/0266242604047412] Vol. 22, No.6, pp. 595-618.

\section{AUTHOR PROFILE}

\section{First Author - Dr. Ravi K S}

Working as an Associate Professor in the Department of Mechanical Engineering, Vidyavardhaka College of Engineering, Mysuru, Karnataka, India.

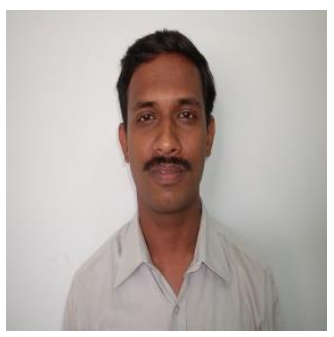

Dr. Ravi K S completed his Bachelor of Mechanical Engineering from University of Mysore, Master of Technology in Master of Engineering Management and Ph.D on Human Resource Management from Visvesvaraya Technological University, Belagavi, India. He is discharging his duties as an Associate professor in the said department from past twenty years. He has been successful in guiding many students in their projects pertinent to Bachelors and Masters programme. Nevertheless he has published many papers in reputed national and International Journals and has 
also presented his research work in national and international conferences. He has served as coordinator and member of various committees to achieve hallmarks such as NBA, NAAC and Autonomy to the Institute. He is a member of Indian Society for Technical Education (ISTE), Member of Board of Studies, Department of Mechanical Engineering, Sri Jayachamarajendra College of Engineering, Mysuru.

\section{Second Author - Dr. Khalid Imran}

Working as an Associate Professor in the Department of Mechanical Engineering, Vidyavardhaka College of Engineering, Mysuru, Karnataka, India.

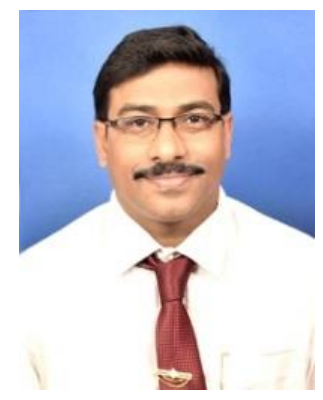

Dr. Khalid Imran completed his Bachelor of Mechanical Engineering, Master of Technology in Master of Engineering Management and Ph.D on Organizational Behaviour from Visvesvaraya Technological University, Belagavi, India. He is discharging his duties as an Associate professor in the said department from past fifteen years. He has been successful in guiding many students in their projects pertinent to Bachelors and Masters programme. Nevertheless he has published many papers in reputed national and International Journals and has also presented his research work in national and international conferences. He has served as coordinator and member of various committees to achieve hallmarks such as NBA, NAAC and Autonomy to the Institute. He is also a single point of contact for the Center of Excellence which imparts training in computer aided design using 3D Experience. He is a member of Indian Society for Technical Education (ISTE), Member of Board of Studies, Department of Mechanical Engineering, Sri Jayachamarajendra College of Engineering, Mysuru, Member of Industry-Academia Board, NIE Institute of Technology, Mysuru. 

